\title{
EFFECT OF LIQUID COW MANURE ON CHEMICAL AND BIOLOGICAL PROPERTIES IN AN ANDISOL
}

\author{
Paula Aguilera ${ }^{1}$, Gabriela Briceño ${ }^{1}$, María de la Luz Mora ${ }^{1}$, Rolando Demanet ${ }^{2}$, \\ Graciela Palma ${ }^{1 *}$
}

\author{
${ }^{1}$ Scientific and Technological Bioresource Nucleus (BIOREN-UFRO), Universidad de la \\ Frontera, Avenida Francisco Salazar 01145, P.O. Box 54-D, Temuco, Chile. ${ }^{2}$ Departamento de \\ Producción Agropecuaria, Universidad de La Frontera, Avenida Francisco Salazar 01145, P.O. \\ Box 54-D, Temuco, Chile.*Corresponding author: gpalma@ufro.cl
}

\begin{abstract}
The aim of this work was to establish the effect of the dose of liquid cow manure (LCM) on some chemical properties and biological activity in an Andisol. This study was carried out under laboratory conditions using an Andisol and LCM from a dairy farm located in the South of Chile. The dose of LCM were the equivalent to 0 (S0), 100 (S100), 200, (S200) and 300 (S300) thousand $\mathrm{L} \mathrm{ha}^{-1}$. This amount is equivalent to regular agronomic LCM applications. The chemical characterization indicated that the LCM addition modified all the tested Andisol chemical properties. These begin to return to the initial conditions from 10 days on, with the exception of EC, K and DOC. The C$\mathrm{CO}_{2}$ evolution indicated that LCM incorporation at increasing dose enhanced the respiratory activity. Enzyme activity was greater in the amended soils than in S0. The results of this study indicated that the period of time necessary for the LCM amended soils returning to a similar behavior to $\mathrm{S} 0$ is more than 10 days, with a strong correlation between the chemical properties of the amended soils and their biological activity, mainly $\mathrm{C}-\mathrm{CO}_{2}$ evolution.
\end{abstract}

Keywords: liquid amendment, biological activities, chemical analysis.

\section{INTRODUCTION}

In recent years, the number of dairies, especially small scale dairies, in southern Chile has increased, and this growth has been accompanied by the intensification of production systems, with milking herd remaining in confinement during the majority of its productive period, fed with large quantities of concentrate, hay and fodder maize (Zea mays L.) silage (Aguilera et al., 2009).

The high feed requirements of the dairies result in the production of large volumes of liquid cow manure (LCM), which are a mixture of cattle urine, faeces, dairy washing water, rainwater and waste food. The LCM is a liquid amendment that contains less than $15 \%$ of dry matter, containing organic matter with a high content in active functional groups, which also generates an increase in the microbial biomass and presents a high content of dissolved organic matter (Salazar, 2007; Briceño, 2008). The LCM has become an important resource, being recycled and incorporated into the production system. This situation is of great importance in southern Chile, since $80 \%$ of the country's dairies are concentrated in this area (ODEPA, 2010). The application of the LCM to the soil is 
considered to be a practical solution due to the beneficial effects of its biological and physicochemical properties (Eghball et al., 2005; Wiederholt et al., 2005), such as increasing the soil organic matter content, contributing to nutrient recycling (Demanet et al., 1999), and increasing microbial activity by the direct addition of microorganisms (Balesdenta et al., 2000; Chantigny et al., 2002), which together help to increase soil fertility due to LCM is an important source of macro and micronutrients (Aguilera, 1995).

Today, the LCM application is recommended in grassland and fodder maize. It has been shown, that a greater production of these crops is achieved by LCM application to the soil, especially in fodder maize used as a feed for milking herds (Demanet et al., 1999). However after LCM application has been observed that dense weed populations emerge and invade the fodder maize crop. Furthermore, there are weed species with a high capacity to capture the nutrients provided by LCM. Then these become invasive species which are difficult to control (Demanet, 1999).

At present, there is no uniform agronomic management of fodder maize in intensive dairy systems in southern Chile with respect to the LCM dose used, which exceed 300 thousand $\mathrm{L} \mathrm{ha}{ }^{-1}$, per year (Demanet et al., 1999; Salazar et al., 2003; Dumont, 2004).

Currently, the use of amendments originated in animal or agricultural waste has become a common worldwide agronomic practice, modifying chemical and biological soil properties (Perucci et al., 2000; Said-Pullicino et al., 2004; Briceño et al., 2007; Perucci et al., 2008). The aim of this study was to evaluate the application effect of increasing LCM dose on the chemical and biological properties in an Andisol. The Andisol under LCM application was analyzed for $\mathrm{pH}$, organic matter (OM), electrical conductivity (EC),
Nitrogen $(\mathrm{N})$, phosphorus $(\mathrm{P})$, potassium $(\mathrm{K})$ and dissolved organic carbon (DOC). The biological activities evaluated were fluorescein diacetate (FDA) hydrolysis , respiratory activity $\left(\mathrm{C}-\mathrm{CO}_{2}\right.$ evolution $)$ and one soil enzyme activity associated to carbon cycling, $\beta$-glucosidase.

\section{MATERIALS AND METHODS}

\section{Soil and LCM}

The Andisol used was a Los Lagos series, mesic, Durudands Typic (Andisol) (CIREN, 2003), with a sandy loam texture (500 $\mathrm{g}$ sand $\mathrm{kg}^{-1}, 480 \mathrm{~g}$ silt $\mathrm{kg}^{-1}, 20 \mathrm{~g}$ clay $\left.\mathrm{kg}^{-1}\right)$, taken from Fundo Santa Isabel, located in Futrono district (40 $03^{\circ}$ ' 34' ' $\mathrm{S}$; $72^{\circ} 32^{\prime} 46^{\prime}$ ' W), Los Rios Region, Chile. The soil was extracted at $0-20 \mathrm{~cm}$ depth, sieved through $2 \mathrm{~mm}$ and air dried.

A single LCM sample was taken, obtained from an open air lagoon located in the area of the dairy farm. This lagoon was built with a cement base and lateral walls operating as an open system. The LCM application dose corresponded to 0 , 100, 200 and 300 thousand $\mathrm{L} \mathrm{ha}^{-1}$. In the laboratory, these doses corresponded to 70, 140 and $210 \mathrm{~mL} \mathrm{~kg}^{-1}$ in one application, assuming LCM distribution in the first $20 \mathrm{~cm}$ of depth and a soil density of $0.75 \mathrm{~g} \mathrm{~mL}^{-1}$.

\section{Chemical LCM and Andisol analyses}

LCM was analyzed following Peters et al. (2003) methodology. EC and $\mathrm{pH}$ were measured in the diluted LCM. For DOC analysis, the LCM was centrifuged, filtered, freeze-dried and analyzed as total organic carbon using a EURO EA 3000 Elemental Analyser with a Callidus software version 4.1. The experiment was done in duplicate. The obtained values were expressed in $\mathrm{mg}$ DOC $\mathrm{L}^{-1}$. Dry matter (DM) content was determined by water evaporation at $70^{\circ} \mathrm{C}$ until constant 
weight. The LCM characteristics were: DM $53.0 \mathrm{~g} \mathrm{~L}^{-1}$, EC $5.9 \mathrm{dS} \mathrm{m}^{-1}$, OM 71.1 $\mathrm{mg} \mathrm{kg}^{-1}$, DOC 2,140 $\mathrm{mg} \mathrm{L}^{-1}, \mathrm{pH} 7.5$, and $\mathrm{N} 28.6 \mathrm{~g} \mathrm{~kg}^{-1}$. DOC in amended and nonamended Andisol was extracted using distilled water in a solid/liquid ratio of 1:10 (w/v) basis dry weight, using $25 \mathrm{~g}$ of soil and $250 \mathrm{~mL}$ of water. These samples were shaken, centrifuged, filtered and freeze-dried. The total organic carbon was analysed using the method indicated above. The Andisol was characterized as previously described by Briceño et al. (2008). The main soil characteristics were

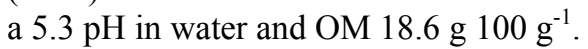

\section{Incubation of the amended Andisol}

After LCM application, the different treatments were incubated for 1, 5, 10, 20, 30,45 and 60 days in a dark room with controlled temperature at $20 \pm 1{ }^{\circ} \mathrm{C}$. The humidity content was adjusted and maintained by the addition of distilled water, whenever necessary. The amended Andisol were characterized chemically after the previously mentioned periods using the same method as for the nonamended Andisol (Table 1).

\section{Biological analyses}

Microbial respiration was determined by measuring $\mathrm{C}-\mathrm{CO}_{2}$ evolution according to the method described by Alef (1995), in which the $\mathrm{CO}_{2}$ produced by the samples is captured by the $\mathrm{NaOH}$ solution and the remainder is titled with $\mathrm{HCl} 0.5 \mathrm{M}$. This vial containing alkali was removed, $\mathrm{BaCl}_{2}$ was added in order to precipitate carbonates, and phenolphthalein was used as indicator. This vial containing alkali was replaced after each measurement. The data were expressed as $\mathrm{C}-\mathrm{CO}_{2} \mu \mathrm{g} \mathrm{g}^{-1}$ soil. The experiment was made in triplicate. The respiratory rate was fitted to a first order kinetic (Matus et al., 2009).

The measurement of FDA hydrolysis was performed using the methodology described by Adam and Duncan (2001). One gram of sample was extracted and placed in $50 \mathrm{~mL}$ centrifuging tubes. A buffer solution of potassium phosphate $7.6 \mathrm{pH}$ was added and enzyme substrate fluorescein diacetate was added, after 10 $\min$. The tubes were closed and incubated at $30{ }^{\circ} \mathrm{C}$ in an orbital incubator at $100 \mathrm{rpm}$ for $20 \mathrm{~min}$, at the end of which a solution of chloroform/methanol (2:1) was added to each tube. Then, tubes were then centrifuged for $20 \mathrm{~min}$ at $3,000 \mathrm{rpm}$. Finally, the fluorescein quantity was determined reading the supernatant in a spectrophotometer at a wavelength of 490 $\mathrm{nm}$. Each evaluation was done in triplicate, with a blank and a control. The activity degree was evaluated on days 1 , $3,5,10,20,30,45$ and 60 .

The data obtained by spectrophotometry were interpolated in a calibration curve using different fluorescein concentration, and then $\mu \mathrm{g}$ fluorescein $\mathrm{g}^{-1}$ dry soil $\mathrm{h}^{-1}$ was calculated. The Andisol under LCM application incubated for 1, 3, 5, 10, 20, 30, 45 and 60 days were used for determining $\beta$ glucosidase activity. The activity of this enzyme was evaluated using the methodology described by Eivazi and Tabatabai (1988).

\section{Statistical Analysis}

In each experiment, the experimental units correspond to the amended Andisol (S0, S100, S200 and S300) contained in the bags, which are extracted from subsamples for each analysis, either for chemical characterization, C- $\mathrm{CO}_{2}$ evolution or for biological analysis. Then, correlation between the chemical and biological properties was carried out. In the correlation analysis, the global behavior of biological and chemical analyses was considered in each treatment during the evaluation time. These results were discussed by variance analysis and 
Manure effect on Andisol properties, Aguilera et al.

Table 1. Chemical characterization of Andisol under liquid cow manure (LCM) application.

\begin{tabular}{|c|c|c|c|c|c|c|c|c|}
\hline $\begin{array}{c}\text { Incubation time } \\
\text { (days) }\end{array}$ & & pH & 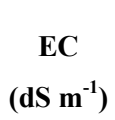 & $\begin{array}{c}\text { OM } \\
\left(\mathrm{g} 100 \mathrm{~g}^{-1}\right)\end{array}$ & $\begin{array}{c}\mathrm{N} \\
\left(\mathrm{g} 100 \mathrm{~g}^{-1}\right)\end{array}$ & $\begin{array}{c}P \\
\left(\mathrm{mg} \mathrm{kg}^{-1}\right)\end{array}$ & $\begin{array}{c}\mathrm{K} \\
\left(\mathrm{mg} \mathrm{kg}^{-1}\right)\end{array}$ & $\begin{array}{c}\text { DOC } \\
\left(\mathrm{mg} \mathrm{kg}^{-1}\right)\end{array}$ \\
\hline \multirow[t]{4}{*}{1} & S0 & $5.3 \mathrm{c}$ & $0.22 \mathrm{~d}$ & $18.6 \mathrm{c}$ & $0.89 \mathrm{~b}$ & $11.1 \mathrm{~d}$ & $105.0 \mathrm{c}$ & $23 \mathrm{~d}$ \\
\hline & $\mathrm{S} 100$ & $5.5 \mathrm{bc}$ & $0.36 \mathrm{c}$ & $18.6 \mathrm{~b}$ & $0.88 \mathrm{~b}$ & $12.2 \mathrm{c}$ & $328.4 \mathrm{~b}$ & $260 \mathrm{c}$ \\
\hline & S200 & $5.7 \mathrm{~b}$ & $0.57 \mathrm{~b}$ & $19.8 \mathrm{~b}$ & $0.98 \mathrm{a}$ & $13.0 \mathrm{~b}$ & $347.9 \mathrm{~b}$ & $360 \mathrm{~b}$ \\
\hline & S300 & $6.0 \mathrm{a}$ & $0.68 \mathrm{a}$ & $23.5 \mathrm{a}$ & $0.98 \mathrm{a}$ & $14.0 \mathrm{a}$ & 598.2 a & $507 \mathrm{a}$ \\
\hline \multirow[t]{4}{*}{5} & S0 & $5.3 \mathrm{~b}$ & $0.21 \mathrm{~d}$ & $18.4 \mathrm{c}$ & $0.92 \mathrm{~b}$ & $12.0 \mathrm{~b}$ & $125.1 \mathrm{~d}$ & $23 \mathrm{~d}$ \\
\hline & S100 & $5.3 \mathrm{ab}$ & $0.31 \mathrm{c}$ & $18.4 \mathrm{c}$ & $0.89 \mathrm{~b}$ & $12.1 \mathrm{~b}$ & $297.1 \mathrm{c}$ & $55 \mathrm{c}$ \\
\hline & S200 & $5.4 \mathrm{ab}$ & $0.50 \mathrm{~b}$ & $20.7 \mathrm{~b}$ & $0.86 \mathrm{~b}$ & $12.18 \mathrm{~b}$ & $324.5 \mathrm{~b}$ & $70 \mathrm{~b}$ \\
\hline & $\mathrm{S} 300$ & $5.6 \mathrm{a}$ & $0.72 \mathrm{a}$ & $23.2 \mathrm{a}$ & $0.95 \mathrm{a}$ & $13.0 \mathrm{a}$ & $625.6 \mathrm{a}$ & $200 \mathrm{a}$ \\
\hline \multirow[t]{4}{*}{20} & S0 & $5.3 \mathrm{~b}$ & $0.22 \mathrm{~d}$ & $18.7 \mathrm{~b}$ & $0.92 \mathrm{c}$ & $10.1 \mathrm{~b}$ & $125.0 \mathrm{~d}$ & $23 \mathrm{~d}$ \\
\hline & $\mathrm{S} 100$ & $5.3 \mathrm{~b}$ & $0.31 \mathrm{c}$ & $18.8 \mathrm{~b}$ & $0.90 \mathrm{bc}$ & $10.2 \mathrm{~b}$ & $308.6 \mathrm{c}$ & $30 \mathrm{c}$ \\
\hline & $\mathrm{S} 200$ & $5.3 \mathrm{~b}$ & $0.48 \mathrm{~b}$ & $19.1 \mathrm{ab}$ & $0.92 \mathrm{~b}$ & $10.2 \mathrm{~b}$ & $368.8 \mathrm{~b}$ & $36 \mathrm{~b}$ \\
\hline & $\mathrm{S} 300$ & $5.7 \mathrm{a}$ & $0.52 \mathrm{a}$ & $19.3 \mathrm{a}$ & $0.96 \mathrm{a}$ & $11.1 \mathrm{a}$ & $539.5 \mathrm{a}$ & $67 \mathrm{a}$ \\
\hline \multirow[t]{4}{*}{30} & S0 & $5.3 \mathrm{~b}$ & $0.24 \mathrm{~d}$ & $17.9 \mathrm{~b}$ & $0.93 \mathrm{~b}$ & $12.0 \mathrm{~b}$ & $125.1 \mathrm{~d}$ & $23 \mathrm{~d}$ \\
\hline & $\mathrm{S} 100$ & $5.3 \mathrm{~b}$ & $0.37 \mathrm{c}$ & $18.0 \mathrm{~b}$ & $0.93 \mathrm{~b}$ & $12.0 \mathrm{~b}$ & $324.5 \mathrm{c}$ & $31 \mathrm{c}$ \\
\hline & S200 & $5.2 \mathrm{~b}$ & $0.46 \mathrm{~b}$ & $19.1 \mathrm{a}$ & $0.91 \mathrm{~b}$ & $12.1 \mathrm{~b}$ & $363.6 \mathrm{~b}$ & $40 \mathrm{~b}$ \\
\hline & $\mathrm{S} 300$ & $5.7 \mathrm{a}$ & $0.51 \mathrm{a}$ & $19.3 \mathrm{a}$ & $0.97 \mathrm{a}$ & $13.0 \mathrm{a}$ & $656.8 \mathrm{a}$ & $71 \mathrm{a}$ \\
\hline \multirow[t]{4}{*}{60} & S0 & $5.3 \mathrm{~b}$ & $0.26 \mathrm{~d}$ & $17.8 \mathrm{a}$ & $0.93 \mathrm{~b}$ & $12.0 \mathrm{~b}$ & $113.3 \mathrm{~d}$ & $23 \mathrm{~d}$ \\
\hline & $\mathrm{S} 100$ & $5.2 \mathrm{~b}$ & $0.31 \mathrm{c}$ & $17.8 \mathrm{a}$ & $0.93 \mathrm{~b}$ & $12.0 \mathrm{~b}$ & $301.0 \mathrm{c}$ & $30 \mathrm{c}$ \\
\hline & S200 & $5.1 \mathrm{~b}$ & $0.47 \mathrm{~b}$ & $18.0 \mathrm{a}$ & $0.91 \mathrm{~b}$ & $12.1 \mathrm{~b}$ & $340.1 \mathrm{~b}$ & $38 \mathrm{~b}$ \\
\hline & $\mathrm{S} 300$ & $5.6 \mathrm{a}$ & $0.52 \mathrm{a}$ & $18.0 \mathrm{a}$ & $0.96 \mathrm{a}$ & $13.3 \mathrm{a}$ & $609.9 \mathrm{a}$ & $70 \mathrm{a}$ \\
\hline
\end{tabular}

Rate of Liquid cow manure (LCM): 0; 100,000; 200,000; and 300,000 L ha ${ }^{-1}$ (S0, S100, S200, and S300, respectively). Different letters indicate significantly different values of each treatment, in a same incubation day, ANOVA with Tukey test, $(P \leq 0.05)$.

multiple range test of Tukey, with prior Levene test application for variance homogeneity.

\section{RESULTS AND DISCUSSION}

\section{Chemical analyses of Andisol under LCM application}

The chemical characterization of the amended and non-amended Andisol was determined over 60 days of incubation
(Table 1). The incorporation of increasing LCM dose modified the soil chemical properties.

The S300 treatment always showed differences in respect to the other LCM dose. On incubation day 1 , the $\mathrm{pH}$ values varied significantly. After 20 incubation days, S0, S100 and S200 were similar, while S300 continued to present a significant difference as compared to the other treatments throughout the 60 incubation days. The OM content on day 1 of incubation presented significant 
differences between S0 and the amended soils. After 5 days S100 was similar to S0.

There were no significant differences after 60 days. The contents of $\mathrm{N}$ and $\mathrm{P}$ from on day 5 of incubation presented no significant differences between S0, S100 and S200. However the $\mathrm{N}$ and $\mathrm{P}$ content of $\mathrm{S} 300$ remained at high levels throughout the whole incubation period. The EC, K content and DOC presented significant differences between the amended soils during the whole incubation period, showing higher values at the highest dose of LCM.

The $\mathrm{pH}$ variation of the amended soils may be explained by the LCM pH close neutral. An increase in the $\mathrm{pH}$ of $\mathrm{S} 300$ is possibly due to higher exchangeable bases content in this treatment (Valarini et al., 2009). Other studies have reported a similar effect on soil $\mathrm{pH}$ after application animal manure (Aguilera et al., 1995; Min et al., 2003; Eghball et al., 2005; Salazar et al., 2007). The increase of $\mathrm{pH}$ has been attributed to buffering effect and organic acid in cattle manure (Whalen et al., 2000). The EC was higher in the soils with a greater LCM dose due to the high content of soluble salts present in the added amendment in the present study (Plaza, 2004). The increase in OM resulting from the application of LCM is due to the addition of external OM with a high $\mathrm{C}$ content and the efficient metabolic activity of the microorganisms present in the soil (Oades, 1984; Bare, 1992; Islam and Weil, 2000; Min, et al., 2003).

Studies carried out in our laboratory indicate that the addition of LCM in increasing dose produces an initial rise in DOC, which falls to its initial condition after 30 days in amended soils S100 and S200, due probably to the stabilization process as $\mathrm{C}$ transformation by microorganisms and adsorption process of DOC in soil. However in S300 it remains higher than in the soil to which no LCM was applied. This increase has been associated with higher DOC content in S300 (Briceño et al., 2008).

\section{Differences in respiratory activity}

The results indicated that the incorporation of LCM has an effect on C$\mathrm{CO}_{2}$ evolution, with a tendency for greater accumulated $\mathrm{C}-\mathrm{CO}_{2}$ evolution as the LCM dose increases, it was observed that $\mathrm{S} 0<\mathrm{S} 100<\mathrm{S} 200<\mathrm{S} 300$. For the highest dose of LCM (S300), the maximum value obtained for accumulated $\mathrm{C}-\mathrm{CO}_{2}$ was 2,092.20 $\mu \mathrm{g} \mathrm{C}-\mathrm{CO}_{2} \mathrm{~g}^{-1}$; for $\mathrm{S} 200$, the value was $1,701.44 \mu \mathrm{g} \mathrm{C}-\mathrm{CO}_{2} \mathrm{~g}$ 1; for $\mathrm{S} 100$, it was $940.88 \mu \mathrm{g} \mathrm{C}-\mathrm{CO}_{2} \mathrm{~g}^{-1}$; and for the soil without liquid manure $632.89 \mu \mathrm{g} \quad \mathrm{C}-\mathrm{CO}_{2} \quad \mathrm{~g}^{-1}$. Significant differences occurred between S0, S100, S200 and S300 for all incubation times (Table 2).

The $\mathrm{C}-\mathrm{CO}_{2}$ evolution rate constant showed that the amended soils presented a higher $\mathrm{C}-\mathrm{CO}_{2}$ evolution on day 1 of incubation. There were significant differences between the treatments, presenting $\mathrm{S} 300$ the highest rate of respiration. The $\mathrm{C}-\mathrm{CO}_{2}$ evolution rate constant $\left(\right.$ day $\left.^{-1}\right)$ of the amended soil decreased to similar levels to those presented by non-amended soils after 10 incubation days (Figure 1).

Studies carried out in agricultural soils which have been planted repeatedly with maize have reported similar behaviours when mineralization was studied. They showed that the highest production of $\mathrm{C}$ $\mathrm{CO}_{2}$ was generated showing the highest production of $\mathrm{C}-\mathrm{CO}_{2}$ being generated in the soils which presented the highest microbial activity (Barriuso and Houot, 1996).

According to the respiration rate the highest level of respiration in this study was obtained on day 1 of incubation, which coincides with studies done by Barriuso and Houot (1996). This occurs because when LCM is applied, an 


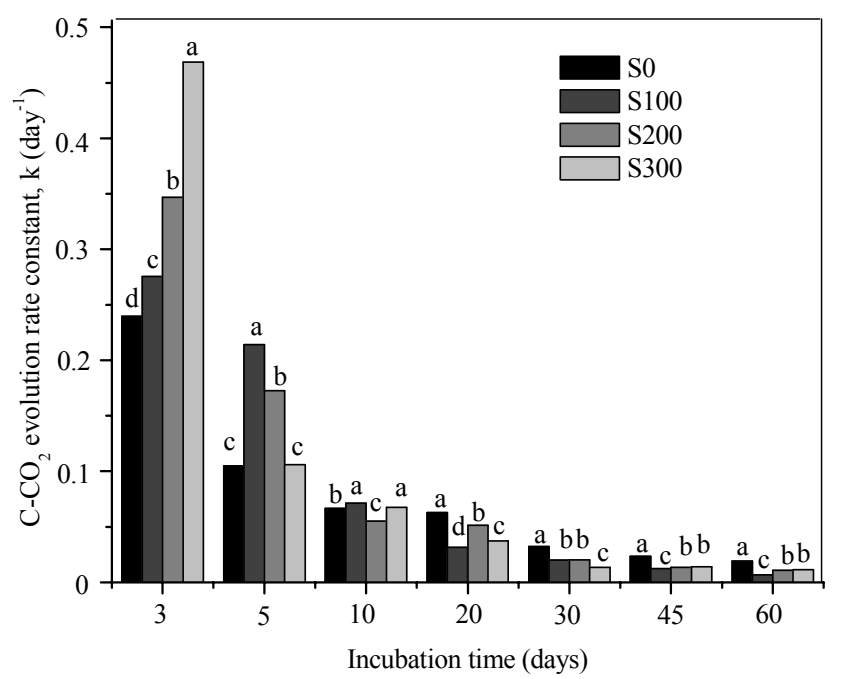

Figure 1. $\mathrm{C}-\mathrm{CO}_{2}$ evolution rate constant from andisol under liquid cow manure (LCM) application. Rate of liquid cow manure (LCM): 0; 100,000; 200,000 and 300,000 L ha ${ }^{-1}$ (S0, S100, S200 and S300, respectively). Different letters indicate significantly different values of each treatment, in a same incubation time, ANOVA with Tukey test, $(P \leq 0.05)$.

Table 2. Cumulative $\mathrm{C}-\mathrm{CO}_{2}\left(\mu \mathrm{g} \mathrm{C}-\mathrm{CO}_{2} \mathrm{~g}^{-1}\right)$ evolution from Andisol under liquid cow manure (LCM) application.

\begin{tabular}{ccccc}
\hline $\begin{array}{c}\text { Incubation time } \\
\text { (days) }\end{array}$ & S0 & S100 & S200 & S300 \\
\hline 1 & $49.60 \mathrm{~d}$ & $84.03 \mathrm{c}$ & $200.36 \mathrm{~b}$ & $259.61 \mathrm{a}$ \\
3 & $80.98 \mathrm{~d}$ & $197.02 \mathrm{c}$ & $393.02 \mathrm{~b}$ & $522.57 \mathrm{a}$ \\
5 & $108.98 \mathrm{~d}$ & $284.02 \mathrm{c}$ & $477.09 \mathrm{~b}$ & $660.73 \mathrm{a}$ \\
10 & $156.39 \mathrm{~d}$ & $390.47 \mathrm{c}$ & $662.62 \mathrm{~b}$ & $937.20 \mathrm{a}$ \\
20 & $271.84 \mathrm{~d}$ & $546.11 \mathrm{c}$ & $972.88 \mathrm{~b}$ & $1275.20 \mathrm{a}$ \\
30 & $383.22 \mathrm{~d}$ & $676.50 \mathrm{c}$ & $1187.88 \mathrm{~b}$ & $1502.20 \mathrm{a}$ \\
45 & $492.89 \mathrm{~d}$ & $795.88 \mathrm{c}$ & $1439.24 \mathrm{~b}$ & $1787.20 \mathrm{a}$ \\
60 & $632.89 \mathrm{~d}$ & $940.88 \mathrm{c}$ & $1701.44 \mathrm{~b}$ & $2092.20 \mathrm{a}$ \\
\hline
\end{tabular}

Rate of liquid cow manure (LCM): 0; 100,000; 200, 000 and 300, $000 \mathrm{~L} \mathrm{ha}^{-1}$ (S0, S100, S200 and S300, respectively). Different letters indicate significantly different values of each treatment, in a same incubation time, ANOVA with Tukey test, $(P \leq 0.05)$.

amendment is being added which has easily degradable substrates, various forms of $\mathrm{C}$ available, and a large quantity of exogenous microorganisms (Mondini et al., 1997; Perucci, 1992). All this aspects can increase microbial activity 
and the biodegradation of the $\mathrm{OM}$ in the soil (Plaza, 2004).

\section{Soil enzymatic activities}

The soil enzymatic activities are summarized in Table 3. The LCM incorporation caused an increased in the FDA hydrolysis of amended soils. However, there was less initial activity in the amended soils than in the nonamended soil during the first 3 incubation days.

Table 3. Fluorescein diacetate (FDA) hydrolysis ( $\mu \mathrm{g}$ fluorescein $\mathrm{g}-1 \mathrm{~h}-1)$ and $\beta$-glucosidase ( $\mu \mathrm{g}$ p-NP g-1 h-1) of Andisol under liquid cow manure (LCM) application.

\begin{tabular}{|c|c|c|c|}
\hline \multirow{2}{*}{$\begin{array}{c}\text { Incubation Time } \\
\text { (days) }\end{array}$} & \multicolumn{3}{|l|}{ Amended } \\
\hline & \multicolumn{3}{|l|}{ Andisol } \\
\hline \multirow[t]{4}{*}{1} & S0 & $537.42 \mathrm{a}$ & $5.9 \mathrm{c}$ \\
\hline & S100 & $441.71 \mathrm{c}$ & $7.0 \mathrm{~b}$ \\
\hline & S200 & $474.02 \mathrm{~b}$ & $7.1 \mathrm{a}$ \\
\hline & S300 & $480.22 \mathrm{~b}$ & $6.8 \mathrm{~b}$ \\
\hline \multirow[t]{4}{*}{3} & S0 & $589.01 \mathrm{a}$ & - \\
\hline & S100 & $499.72 \mathrm{~b}$ & - \\
\hline & S200 & $493.73 \mathrm{~b}$ & - \\
\hline & S300 & $493.96 \mathrm{~b}$ & - \\
\hline \multirow[t]{4}{*}{5} & S0 & $536.85 \mathrm{~b}$ & - \\
\hline & S100 & $529.59 \mathrm{~b}$ & - \\
\hline & S200 & $518.18 \mathrm{~b}$ & - \\
\hline & S300 & $594.64 \mathrm{a}$ & - \\
\hline \multirow[t]{4}{*}{10} & S0 & $544.98 \mathrm{c}$ & $7.1 \mathrm{c}$ \\
\hline & S100 & $772.24 \mathrm{~b}$ & $8.5 \mathrm{a}$ \\
\hline & S200 & $813.34 \mathrm{a}$ & $7.8 \mathrm{~b}$ \\
\hline & S300 & $844.75 \mathrm{a}$ & $8.6 \mathrm{a}$ \\
\hline \multirow[t]{4}{*}{20} & So & $640.03 \mathrm{c}$ & $9.4 \mathrm{c}$ \\
\hline & S100 & 998.74 b & $9.8 \mathrm{~b}$ \\
\hline & S200 & $1145.93 \mathrm{a}$ & $9.8 \mathrm{~b}$ \\
\hline & S300 & $1100.52 \mathrm{a}$ & $10.2 \mathrm{a}$ \\
\hline \multirow[t]{4}{*}{30} & S0 & $570.35 \mathrm{~d}$ & $5.3 \mathrm{c}$ \\
\hline & S100 & $937.20 \mathrm{~b}$ & $4.8 \mathrm{~d}$ \\
\hline & S200 & $992.51 \mathrm{a}$ & $5.6 \mathrm{~b}$ \\
\hline & S300 & $834.85 \mathrm{c}$ & $6.8 \mathrm{a}$ \\
\hline \multirow[t]{4}{*}{45} & S0 & $386.32 \mathrm{c}$ & - \\
\hline & S100 & $636.67 \mathrm{a}$ & - \\
\hline & S200 & $584.13 \mathrm{~b}$ & - \\
\hline & S300 & $642.63 \mathrm{a}$ & - \\
\hline \multirow[t]{4}{*}{60} & S0 & $466.51 \mathrm{c}$ & - \\
\hline & S100 & $566.83 \mathrm{~b}$ & - \\
\hline & S200 & $543.86 \mathrm{~b}$ & - \\
\hline & S300 & $620.36 \mathrm{a}$ & - \\
\hline
\end{tabular}

Rate of Liquid cow manure (LCM): 0;100,000; 200, 000 and 300, $000 \mathrm{~L} \mathrm{ha}^{-1}(\mathrm{~S} 0, \mathrm{~S} 100, \mathrm{~S} 200$ and S300, respectively). Different letters indicate significantly different values of each treatment, in a same incubation time, ANOVA with Tukey test, $(P \leq 0.05)$. 
The FDA hydrolysis increased from $537.42 \mu \mathrm{g}$ fluorescein $\mathrm{g}^{-1} \mathrm{~h}^{-1}$ representing the soil initial activity, to $1145.93 \mu \mathrm{g}$ fluorescein $\mathrm{g}^{-1} \mathrm{~h}^{-1}$ and $1100.52 \mu \mathrm{g}$ fluorescein $\mathrm{g}^{-1} \mathrm{~h}^{-1}$, after 20 evaluation days in the S200 y S300 treatments, respectively. These values decreased at the final evaluation; however S300 remained with a higher value.

The behaviour of FDA hydrolysis on days 1 and 3 of incubation may be explained as an enzyme inhibition produced by the addition of the amendment to the microbial biomass, which from day 5 would begin the production of hydrolytic enzymes as a symptom of this effect. Some of these enzymes might be of endocellular origin, derived by cell lysis (Perucci et al., 2000). The increase in the FDA hydrolysis after 3 incubation days indicates a higher activity of the microorganisms due to nutrients contribution, $\mathrm{pH}$ increment and OM present in the LCM. These factors contributed to the development soil microorganisms (Gallardo et al., 2010).

Other study relates FDA hydrolysis to the degree of composting of the amendment added (Sánchez-Monedero et al., 2008), and also suggests that it can be used to measure of the hydrolytic activity of the microorganisms in the soil (Dumonet et al., 1993). The fluorescein diacetate hydrolysis becomes stabilizes again when the $\mathrm{OM}$ in an amendment becomes stabilized, since a smaller quantity of hydrolytic enzymes is available (Perucci et al., 2000). The stabilization process may be considered as the transformation of $\mathrm{C}$ through the mineralization carried out by the microorganisms in the soil (Kalbitz et al., 2003), which lead to a constant activity of the microorganisms.

In the present study, the $\beta$-glucosidase activity showed a significant effect $(P \leq 0.05)$ of LCM application (Table 3$)$. The $\beta$-glucosidase activity increased from
$5.9 \mu \mathrm{g} p$-NP $\mathrm{g}^{-1} \mathrm{~h}^{-1}$, representing the activity of the non-amended soil, up to $10.2 \mu \mathrm{g} p$-NP $\mathrm{g}^{-1} \mathrm{~h}^{-1}$ in the $\mathrm{S} 300$ treatment, after 20 incubation days. These values decreased over the 30 incubation days, except for S300 treatment.

The $\beta$-glucosidase activity has been evaluated in soils from southern Chile under different tillage system being positively related with the total soil carbon (Alvear et al., 2005). The results obtained in this study showed that $\beta$ glucosidase activity increased as amendment was added to the soil, coinciding with the findings of Deng and Tabatabai (1996), who found that the activity of this enzyme rises with increased accumulation of $\mathrm{OM}$ and carbon content in the soil. Various studies indicate that $\beta$-glucosidase activity is related to the soil OM content, its humidity and the transformation produced by the microorganisms to obtain energy. The application of liquid cow manure provides a source of available $\mathrm{C}$ which serves as a source of energy especially for enzymes related to the carbon cycle (García-Gil et al., 2004).

\section{Correlation Analyses between chemical and biological amended Andisol properties}

The physicochemical properties were analyzed in correlation with the $\mathrm{C}-\mathrm{CO}_{2}$ evolution and with FDA hydrolysis (Table 4)

A significant inverse correlation was found between the $\mathrm{C}-\mathrm{CO}_{2}$ evolution in amended soils and their $\mathrm{pH}$ values, with S200 and S300 presenting the greatest correlation, indicating that as $\mathrm{pH}$ values reduced over time, there was greater $\mathrm{C}$ $\mathrm{CO}_{2}$ evolution

The EC and the $\mathrm{C}-\mathrm{CO}_{2}$ evolution of the S200 and S300 treatments also showed a significant inverse correlation, indicating that the $\mathrm{C}-\mathrm{CO}_{2}$ evolution 
Table 4. Correlation coefficients between fluorescein diacetate (FDA) hydrolysis and cumulative $\mathrm{C}_{-} \mathrm{CO}_{2}$ evolution, and chemical properties of Andisol under liquid cow manure (LCM) application.

\begin{tabular}{|c|c|c|c|c|c|c|c|c|c|c|c|c|c|c|c|c|c|c|}
\hline & \multicolumn{3}{|c|}{ pH } & \multicolumn{3}{|c|}{ EC } & \multicolumn{3}{|c|}{$\mathbf{O M}$} & \multicolumn{3}{|c|}{$\mathbf{N}$} & \multicolumn{3}{|c|}{$\mathbf{P}$} & \multicolumn{3}{|c|}{$\mathbf{K}$} \\
\hline $\mathrm{FDA}^{\mathrm{a}}$ & S100 & S200 & S300 & S100 & S200 & S300 & S100 & S200 & $\mathrm{S} 300$ & S100 & S200 & S300 & S100 & S200 & S300 & S100 & S200 & S300 \\
\hline $\mathrm{S} 100$ & -0.21 & & & 0.21 & & & 0.04 & & & $0.48^{*}$ & & & $-0.41^{*}$ & & & 0.39 & & \\
\hline S200 & & -0.40 & & & $0.53^{* *}$ & & & 0.03 & & & 0.32 & & & $-0.74^{* *}$ & & & 0.25 & \\
\hline & & & -0.40 & & & $0.62^{* *}$ & & & -0.20 & & & 0.09 & & & $-0.76^{* *}$ & & & 0.35 \\
\hline & & & & & & & & & & & & & & & & & & \\
\hline $\mathrm{S} 100$ & $-0.47^{*}$ & & & -0.13 & & & $0.85^{* *}$ & & & $-0.55^{* *}$ & & & $0.47^{*}$ & & & $0.99^{* *}$ & & \\
\hline S200 & & $-0.87^{* *}$ & & & $-0.72^{* *}$ & & & $0.85^{* *}$ & & & $-0.78^{* *}$ & & & 0.03 & & & $0.99^{* *}$ & \\
\hline S300 & & & $-0.71^{* *}$ & & & $-0.88^{* *}$ & & & $0.54^{* *}$ & & & $-0.74^{* *}$ & & & 0.19 & & & $0.99^{* *}$ \\
\hline
\end{tabular}

Asterisks (* and **) indicate significant difference at $P=0.05$ and $\mathrm{P}=0.01$, respectively. Rate of LCM: $0 ; 100,000 ; 200,000$ and 300 , $000 \mathrm{~L} \mathrm{ha}^{-1}$ (S0, S100, S200 and S300, respectively). EC: Electrical conductivity; OM: organic matter; N: nitrogen; P: phosphorus; K: potassium. ${ }^{\mathrm{a}} \mu \mathrm{g}$ fluorescein $\mathrm{g}^{-1} \mathrm{~h}^{-1} \cdot{ }^{\mathrm{b}} \mu \mathrm{g} \mathrm{C}-\mathrm{CO}_{2} \mathrm{~g}^{-1}$. 
increased as the EC values diminished. A positive correlation was found in the analysis between $\mathrm{C}-\mathrm{CO}_{2}$ and $\mathrm{OM}$, suggesting that the $\mathrm{C}-\mathrm{CO}_{2}$ evolution of all the amended soils was greater when the OM content was higher. For the elements $\mathrm{N}, \mathrm{P}$ and $\mathrm{K}$, there was no correlation between $\mathrm{C}-\mathrm{CO}_{2}$ and $\mathrm{P}$, however a significant inverse correlation was found between $\mathrm{C}-\mathrm{CO}_{2}$ and the $\mathrm{N}$ content, and a high positive correlation was shown between $\mathrm{C}-\mathrm{CO}_{2}$ and the $\mathrm{K}$ content in all the amended soils.

There was no general trend of correlation with respect to FDA hydrolysis, except between FDA hydrolysis and the $\mathrm{P}$ content, for which S200 and S300 showed the highest significant inverse correlation. These relations would indicate that the chemical properties influence microbial activity specially those evaluated by FDA hydrolysis and $\mathrm{C}-\mathrm{CO}_{2}$ indicators.

Studies carried out by Plaza (2004) and Albarrán et al., (2004), who used amendments originating from pig production, found that the application of OM added easily degradable compounds, which favours microbial activity and the biodegradation of the OM. Furthermore the incorporation of LCM generates an initial ammonification process as described above and an increase in the concentration of the soluble salts which characterize the LCM (Plaza, 2004).

In the present study a higher respiration rate was found at the start of incubation, which coincides with the greater OM values, subsequently these values start to return to soil values and the respiration rate starts to fall, which would occur due to the stabilization processes occurring in the soil (Kalbitz et al., 2003). According to previous studies, this process starts 10 days after the application of the LCM using the same soil (Aguilera et al., 2009).

\section{CONCLUSIONS}

The incorporation of increasing dose of LCM modified soil chemical properties. High dose of LCM application resulted in increased the $\mathrm{pH}$ values, $\mathrm{EC}, \mathrm{OM}$ content, nutrients and DOC. The highest amendment dose presented a significant difference as compared to the other treatments throughout the 60 incubation days. The respiration activity of the amended soils increased with the increasing dose of LCM. The $\mathrm{C}-\mathrm{CO}_{2}$ evolution rate constant showed that amended soils presented a higher $\mathrm{C}-\mathrm{CO}_{2}$ evolution levels on 1 incubation day. The amended soils which were incubated for more than 10 days presented a constant rate of respiration. The soil enzymatic activities indicated that LCM incorporation caused an increased in the FDA hydrolysis and the $\beta$-glucosidase of amended soils. Although there was an initial inhibition in the FDA hydrolysis.

In the study it was found that the incorporation of increasing dose of LCM modified the chemical and biological properties of the soil and that there is a correlation between the chemical properties of the soils amended and the biological activity, mainly $\mathrm{C}-\mathrm{CO}_{2}$ evolution. An adequate LCM utilization could to contribute to improve the Management Practices in the intensive dairy systems in southern Chile.

\section{ACKNOWLEDGEMENTS}

This study was financed by the project FONDECYT 1070568.

\section{REFERENCES}

Adam, G., Duncan, H. 2001. Development of a sensitive and rapid method for the measurement of total microbial activity using fluorescein diacetate (FDA) in a range of soils. Soil Biol. Biochem. 33, 943-951. 
Aguilera, P., Briceño, G., Candia, M., Mora, ML., Demanet, R., Palma, G. 2009. Effect of dairy manure rate and the stabilization time of amended soils on atrazine degradation Chemosphere 77, 785-790.

Aguilera, S., Borie, G., Mora, ML. y Demanet, R. 1995. Los purines en la fertilidad del suelo. Frontera Agrícola (Chile) 3 (1) 36-42.

Aguilera, S., Borie, G., Peirano, P., Mora, ML., Demanet, R. 1995. Caracterización de purines para su potencial uso como fertilizante y mejorador de suelos. Agric. Téc. (Chile) 55, 251256.

Albarrán, A., Celis, R., Hermosín, M., LópezPiñeiro, A., Cornejo, J. 2004. Behaviour of simazine in soil amended with the final residue of the olive-oil extraction process. Chemosphere $54,717-724$.

Alef, K. 1995. Estimation of soil respiration. In: K. Alef y P. Nannipieri (Eds). Methods in Applied Soil Microbiology and Biochemistry. Academic Press, London. pp. 464-467.

Alvear, M., López, R., Rosas, A., Rouanet, J. Borie, F. 2005. Effects of three soil tillage systems on some biological activities in an Ultisol from southern Chile. Soil Till. Res. 82, 195-202.

Balesdenta, J., Chenub, C., Balabaneb, M. 2000. Relationship of soil organic matter dynamics to physical protection and tillage. Soil Till. Res. 53, 215-230.

Beare, M., Parmelee, R., Hendrix, P., Cheng, W., Coleman, D., Crossley, A. 1992. Microbial and faunal interactions and effects on litter nitrogen and decomposition in agroecosystems. Ecol. Monogr. 6, 569-591.

Barriuso, E., Houot, S. $1996 . \quad$ Rapid mineralization of the s-triazine ring of atrazine in soils in relation to soil management. Soil Biol. Biochem. 28, 1341-1348.

Briceño, G., Palma, G., Durán, N. 2007. Influence of organic amendment on the biodegradation and movement of pesticides. Crit. Rev. Env. Sci. Tec. 37, 233-271.

Briceño, G., Demanet, R., Mora, ML., Palma, G. 2008. Effect of liquid cow manure on andisol properties and atrazine adsorption. J. Environ. Qual. 37, 1519-1526.

CIREN. 2003. Descripciones de suelos, materiales y símbolos. Estudio agrológico $\mathrm{X}$
Región. Tomo II. 412 p. Publicación $\mathrm{N}^{\circ} 123$ Centro de Información de Recursos Naturales (CIREN), Santiago (Chile). Available in http://www.ciren.cl/cirenxml/informacion/suelos /es publicaciones.htm.

Chantigny, M., Angers, D., Rochette, P. 2002. Fate of carbon and nitrogen from animal manure and crop residues in wet and cold soils. Soil Biol. Biochem. 34, 509-517.

Demanet, R., Aguilera, M., Mora, M. 1999. Efecto de la aplicación de purines sobre el sistema suelo-planta. Frontera Agrícola. (Chile) 5, 87-94.

Deng, S., Tabatabai, M. 1996. Effect of tillage and residue management on enzyme activities in soils. II Glycosidases. Biol.Fertil.Soils. 22, 208213.

Dumont, J. 2004. Manejo eficiente de purines. In: I.d.I. Agropecuarias (Editor), Informativo Remehue $\mathrm{N}^{\circ}$ 21, Osorno (Chile).

Dumontet, S., Perucci, P., Scopa, A., Ricciardi, A. 1993. Solfonylureas: preliminary study on the effect on selected microbial strains and soil respiration. Soil Sci. 1, 193-198.

Entry, J., Emmingham, W. 1995. The influence of dairy manure on atrazine and 2,4dichlorophenoxyacetic acid mineralization in pasture soils. Can. J. Soil Sci. 75, 379-383.

Eghball, B., Wienhold, B., Woodbury, B., Eigenberg, R. 2005. Plant availability of phosphorus in swine slurry and cattle feedlot manure. Agron. J. 97, 542-548.

Farenhorst, A., Reimer, M., Londry, K. Saiyed, I. 2006. 2,4-Dichlorophenoxy acetic acid mineralization in amended soil. J. Env. Sci.Heal. B 41, 509-522.

Gallardo, F., Bravo, C., Briceño, G., Diez M.C. 2010. Use of sludge from Kraft mill wastewater treatment as improver of volcanic soils: Effect on soil biological parameters. J. Soil Sc. Plant. Nutr. 6, 64-83.

García-Gil, J., Plaza, C., Senesi, N., Brunetti, G., Polo, A. 2004. Effects of sewage sludge amendment of humic acids and microbiological properties of a semiarid Mediterranean soil. Biol. Fertil.Soils. 39, 320-328.

Getenga, Z. 2003. Enhanced mineralization of atrazine in compost-amended soil in laboratory studies. B. Environ. Contam. Tox. 71, 933-941. 
Houot, S., Topp, E., Yassir, A., Soulas, G. 2000. Dependence of accelerated degradation of atrazine on soil $\mathrm{pH}$ in french and canadian soils. Soil Biol. Biochem. 32, 615-625.

Houot, S., Barriuso, E., Bergheaud, V. 1998. Modification to atrazine degradation pathways in loamy soil after addition of organic amendments. Soil Biol. Biochem. 30, 2147-2157.

Huang, X., Lee, S. 2001. Effects of dissolved organic matter from animal waste effluent on chlorpyrifos sorption by soils. J. Environ. Qual. 30:1258-1265.

Islam, K., Weil, R. 2000. Soil quality indicator properties in mid-Atlantic soils as influenced by conservation management. J. Soil Water Conserv. $55,69-78$.

Kalbitz, K., Schwesig, D., Schmerwitz, J., Kaiser, K., Haumaier, L., Glaser, B., Ellerbrock, R., Leinweber, P. 2003. Changes in properties of soil derived dissolved organic matter induced by biodegradation. Soil Biol. Biochem. 35, 1129-1142.

Matus, F., Panichini, M., Godoy, R., Borie, F. 2009. Soil carbon storage in allophanic soils: Study of a pristine Nothofagus pumilio in the upper altitudinal limit of temperate rain forest. Academia Press. Belgium (in Press).

Min, D., Islam, K., Vough, L., Weil, R. 2003. Dairy manure effects on soil quality properties and carbon sequestration in alfalfa-orchard grass systems. Comm. Soil Sci. Plant Anal. 34, 781799

Moorman, T., Cowan, J., Arthur, E., Coats, J. 2001. Organic amendments to enhance herbicide biodegradation in contaminated soils. Biol. Fertil. Soils. 33, 541-545.

Mondini, C., Sánchez-Monedero, M., Leita, L., Bragato, G., De Nobili, M. 1997. Carbon and ninhydrin-reactive nitrogen of the microbial biomass in rewetted compost samples. Commun. Soil Sci. Plant Anal. 28, 113-122.

Oades, J.M. 1984. Soil organic matter and structural stability: mechanisms and implications for management. Plant Soil. 76, 319-337.

ODEPA, 2010. Ministerio de Agricultura (Chile). Estadísticas lácteas semestrales. Available in www.odepa.cl.

Perucci, P. 1992. Enzyme activity and microbial biomass in a field soil amended with municipal refuse. Biol. Fert. Soils. 14, 54-60
Perucci, P., Dumontet, S., Bufo, S., Mazzatura, A., Casucci, C. 2000. Effects of organic amendent and herbicide treatment on soil microbial biomass. Biol. Fertil. Soils. 32, 17-23.

Perucci, P., Monaci, E., Onofri, A., Vischetti, C., Cassucci, C. 2008. Changes in physicchemical and biochemical parameters of soil following addition of wood ash: a field experiment. Eur. J. Agron. 28, 155-161.

Plaza, C., Hernández, D., García-Gil, J., Polo, A. 2004. Microbial activity in pig slurry-amended soils under semiarid conditions. Soil Biol. Biochem. 36,1577-1585.

Salazar, F., Dumont, J., Santana, M., Pain, B., Chadwick, D., \& Owen. E. 2003. Prospección del manejo y utilización de purines de lecherías en el Sur de Chile. Arch. Med. Vet. (Chile) 35, 215-225.

Salazar, F., Dumont, J., Chadwick, D. 2007. Caracterización de purines de lecherías en el Sur de Chile. Agric. Téc. (Chile) 67 (2), 155-162.

Sánchez-Monedero, M., Mondini, C., Cayuela, M., Roig, A., Contin, M., De Nobili, M. 2008. Fluorescein diacetate hydrolysis, respiration and microbial biomass in freshly amended soils. Biol. Fertil. Soils. 44, 885-890.

Sluszny, C., Graber, E., Gerstl, Z. 1999. Sorption of s-triazine herbicides in organic matter amendment soils: fresh and incubated systems. Water Air Soil Poll. 115, 395-410.

Valarini, P., Curaqueo, G., Seguel, A., Manzano, K., Rubio, R., Cornejo, P., Borie, F. 2009. Effect of compost application on some properties of a volcanic soil from central South Chile. Chilean J. Agric. Res. 69 (3) 416-425.

Whalen, J., Chang, C., Clayton, G., Carefoot, J. 2000. Cattle manure amendements can increase the $\mathrm{pH}$ of acidic soils. Soil. Sci. Soc. Am. J. 64, 962-966.

Wanner, U., Fuhr, F., Burauel, P. 2005. Influence of the amendment of corn straw on the degradation behavior of the fungicide dithianon in soil. Environ. Pollut. 133, 63-70.

Wiederholt, R., Franzen, D., Johnson, B. 2005. Livestock Manure Utilization in No-till cropping systems. NDSU Extension Service, North Dakota State University of Agriculture and Applied Science. 701, 231-7881. 